RESIDENT

\& FELLOW

SECTION

Section Editor

Mitchell S.V. Elkind,

MD, MS

Suvasini Sharma, MD,

DM

Naveen Sankhyan, MD, DM

Madhulika Kabra, MD

Sheffali Gulati, MD

Address correspondence and reprint requests to Dr. Sheffali Gulati, Child Neurology Division, Department of Pediatrics, All India Institute of Medical Sciences, New Delhi, 110029 India

sheffaligulati@gmail.com

\section{Teaching NeuroImages: T2 hypointense thalami in infantile GM1 gangliosidosis}
Figure MRI of brain

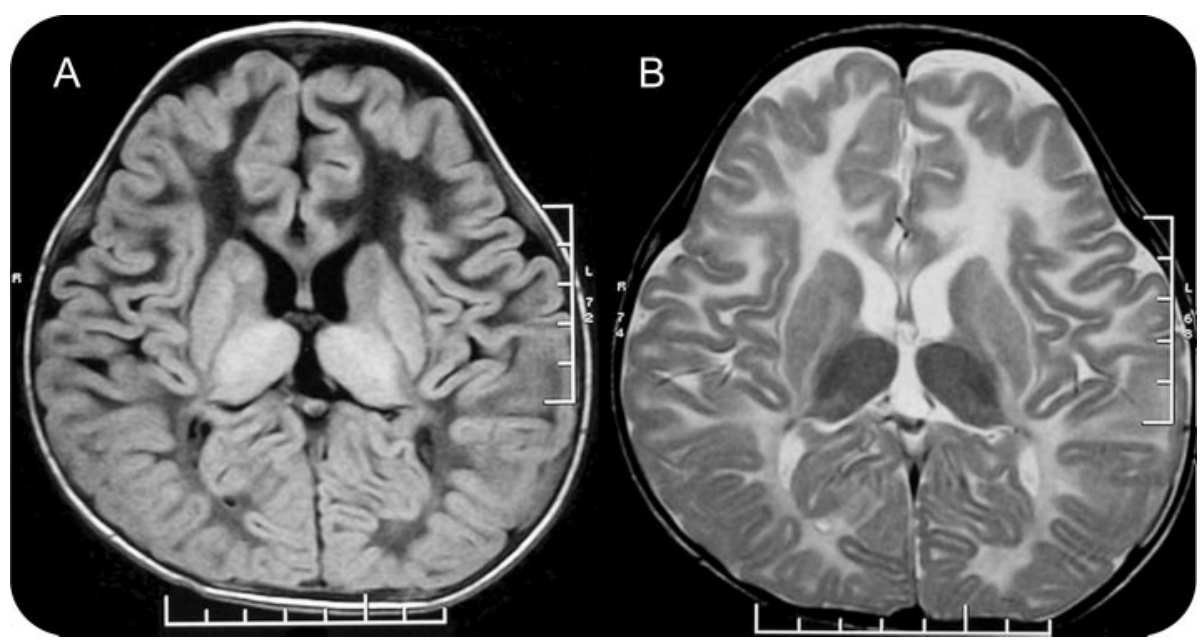

Axial T1-weighted images (A) and T2-weighted images (B) at the level of thalami show diffuse dysmyelination of hemispheric white matter with bilaterally symmetric thalamic signal change which appear hyperintense on T1-weighted and hypointense on T2-weighted images. Additionally, the thalami and basal ganglia show subtle nonhomogeneous mixed low and high signals on both images.

A 13-month-old boy was evaluated for seizures and developmental regression. He was well until the age of 9 months. Then he developed generalized tonic seizures and progressive loss of ability to sit, hold neck, interact, and smile. Examination revealed coarse facies, bilateral macular cherry red spots, and hepatosplenomegaly. A suggestive MRI of brain (figure) and absent $\beta$-galactosidase enzyme activity in leukocytes confirmed the diagnosis of GM1 gangliosidosis.

Accumulation of GM1 gangliosides in the neurons can increase tissue viscosity. This possibly leads to hypointensity of thalami on T2-weighted images. Similar changes in the thalami have been reported in other lysosomal storage disorders. ${ }^{1}$

\section{AUTHOR CONTRIBUTIONS}

N.S. and S.S. performed the clinical/diagnostic workup of the child and reviewed the literature. M.K. and S.G. were in charge of the case overall and approved the manuscript.

\section{REFERENCE}

1. Autti T, Joensuu R, Aberg L. Decreased T2 signal in the thalami may be a sign of lysosomal storage disease. Neuroradiology 2007;49:571-578. 


\section{Neurology}

Teaching NeuroImages: T2 hypointense thalami in infantile GM1 gangliosidosis

Suvasini Sharma, Naveen Sankhyan, Madhulika Kabra, et al.

Neurology 2010;74;e47

DOI 10.1212/WNL.0b013e3181d5a44e

This information is current as of March 22, 2010

Updated Information \&

Services

References

Subspecialty Collections

Permissions \& Licensing

Reprints including high resolution figures, can be found at: http://n.neurology.org/content/74/12/e47.full

This article cites 1 articles, 0 of which you can access for free at: http://n.neurology.org/content/74/12/e47.full\#ref-list-1

This article, along with others on similar topics, appears in the following collection(s):

All Cognitive Disorders/Dementia

http://n.neurology.org/cgi/collection/all_cognitive_disorders_dementia All Pediatric

http://n.neurology.org/cgi/collection/all_pediatric

Metabolic disease (inherited)

http://n.neurology.org/cgi/collection/metabolic_disease_inherited

MRI

http://n.neurology.org/cgi/collection/mri

Information about reproducing this article in parts (figures,tables) or in its entirety can be found online at:

http://www.neurology.org/about/about_the_journal\#permissions

Information about ordering reprints can be found online:

http://n.neurology.org/subscribers/advertise

Neurology ${ }^{\circledR}$ is the official journal of the American Academy of Neurology. Published continuously since 1951, it is now a weekly with 48 issues per year. Copyright . All rights reserved. Print ISSN: 0028-3878. Online ISSN: 1526-632X.

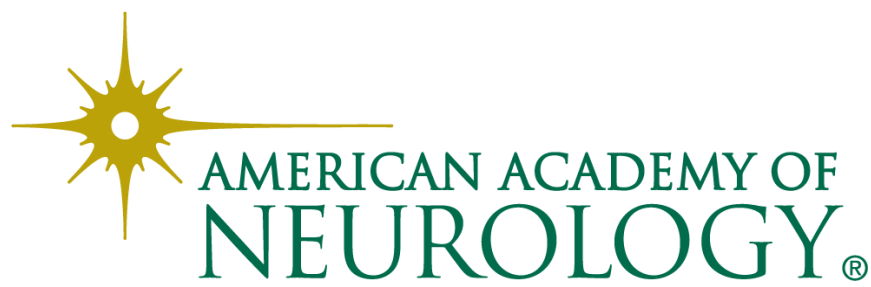

